\title{
Prognostic value of neutrophil- lymphocyte ratio, platelet-lymphocyte ratio and systemic immune-inflammatory index in resected gastric cancer
}

\section{Hayriye Şahinli, Sema Turker}

Department of Medical Oncology, Ankara Dıșkapı Ylldırım Beyazıt Training and Research Hospital, Ankara, Turkey

Received: 2019-12-29

Accepted: 2020-01-06

UDC:618.1

J Clin Med Kaz 2019; 4(54):34-39

Corresponding Author: Hayriye Sahinli, Ankara Dışkapı Yıldırım Beyazıt Training and Research Hospital, Medical Oncology, Ankara, Turkey. ORCID No: 0000-0002-1561-9346. Tel.: 05536934969

E-mail: dr.hayriye@hotmail.com

\section{Abstract}

Objective: The prognostic value of neutrophil-lymphocyte ratio, plateletlymphocyte ratio and systemic immune-inflammatory index has been studied in many cancer types. Our aim is to show the prognostic value of neutrophillymphocyte ratio, platelet-lymphocyte ratio and systemic immune-inflammatory index in resected gastric cancer patients. In addition, to determine which parameter is a better predictor of survival.

Material and methods: The study included 95 patients resected gastric cancer between 2014-2018. Receiver operating curve analysis was used to determine neutrophil-lymphocyte ratio, platelet-lymphocyte ratio and systemic immune-inflammatory index cut-off values. Systemic immune-inflammatory index was evaluated asneutrophil $\times$ platelet/lymphocyte. Long rank and cox regression analysis were used.

Results: The median age was $62(22-84)$ years. The median overall survival was 33 months. $49(51.6 \%)$ patients were in stage 3 and $46(48.4 \%)$ patients were in stage 1-2. High neutrophil-lymphocyte ratio, platelet-lymphocyte ratio and systemic immune-inflammatory index values, tumor depth, stage of metastatic lymph node and tumor-node-metastasis stage were poor prognostic factors for overall survival and disease-free survival. When multivariant cox regression analysis was performed, only platelet-lymphocyte ratio was found to be independent prognostic factor ( $p=0.037$ for overall survival, $p=0.024$ for overall survival).

Conclusion: High neutrophil-lymphocyte ratio, platelet-lymphocyte ratio and systemic immune-inflammatory index were found to be poor prognostic factors in predicting both overall survival and disease-free survival before treatment in patients who undergo curative resection for gastric cancer. As a result of multivariant analysis, only high platelet-lymphocyte ratio was determined as an independent poor prognostic factor for both overall survival and disease-free survival.

Keywords: gastric cancer, neutrophil-lymphocyte ratio, plateletlymphocyte ratio, prognosis

\section{НЕЙТРОФИЛДЕР МЕН ЛИМФОЦИТТЕРДІН ҚАТЫНАСЫ ИНДЕКСІНІН, ТРОМБОЦИТТЕР МЕН ЛИМФОЦИТТЕРДІҢ ҚАТЫНАСЫ ИНДЕКСІНІҢ ЖӘНЕ РЕЗЕКЦИЯЛАНҒАН АСҚАЗАН ҚАТЕРЛІ ІСІГІНІН ЖУЙЕЛІК ИММУНДЫҚ ҚАБЫНУ ИНДЕКСІНІҢ БОЛЖАМДЫҚ МӘНІ}

Х. Шахинли, С. Туркер

Медициналық онкология бөлімі, Дышкапы Йылдырым Беязит Анкара Университет ауруханасы, Анкара, Түркия

\section{ТҰЖЫРЫМДАМА}

Мақсаты: Қатерлі ісік ауруының көптеген түрлерінде нейтрофилдер мен лимфоциттердің қатынасы индексінің, тромбоциттер мен лимфоциттердің қатынасы индексінің және жүйелік иммунды-қабыну индексінің болжамдық мәні зерттелген. Біздің зерттеуіміздің мақсаты нейтрофилдің лимфоциттерге қатынасының индексіне, тромбоциттердің лимфоциттерге қатынасы индексіне және асқазанның қатерлі ісігі бар науқастарда жүйелік иммунды-қабыну көрсеткішін көрсету. Сондай-ақ тірі қалу үшін қандай параметр ең жақсы болжамдық фрактор екенін анықтау. 
Материалдары және әдістері: Зерттеуге 2014 жылдан 2018 жылға дейінгі аралықта резекцияланған асқазан обырымен ауыратын 95 пациент кірді. Нейтрофилдер мен лимфоциттердің қатынасы индексінің, тромбоциттер мен лимфоциттердің арақатынасы индексінің шекті мәндерін және жүйелік иммунды-қабыну индексін анықтау үшін қабылдағыштың операциялық сипаттамасының қисық сызбасына талдау жасалды. Жүйелік иммунды-қабыну индексі нейтрофрил × тромбоциттер / лимфоциттер ретінде есептелді. Логарифрмдік дәрежелік тест және Кокстің регрессиялық талдауы қолданылды.

Нәтижелері: Науқастардың орташа жасы 62 (22-84) жасты құрады. Жалпы өмір сүру ұзақтығы 33 ай болды. 49 (51,6\%) пациентте 3 саты болды, ал 46 (48,4\%) науқаста 1-2 саты болды. Нейтрофилдің лимфоциттерге қатынасы индексінің, тромбоциттердің лимфоциттерге қатынасы индексінің және жүйелік иммунды-қабыну индексінің, ісік тереңдігінің, метастатикалық лимфа түйінінің сатысы мен қатерлі ісіктерді жіктеу жүйесінің сатысы жалпы өмір сүруге және рецедивсіз өмір сүру үшін қолайсыз болжамдық факторлар болып табылды.

Кокс регрессиясына көпжақты талдау жүргізгеннен кейін тромбоциттер мен лимфоциттердің ара қатынасы тәуелсіз болжам факторы болып табылатыны анықталды (жалпы өмір сүру үшін $p=0.037$, рецедивсіз өмір сұру үшін $p=0.024$ ).

Қорытынды: Асқазан қатерлі ісігінің радикалды хирургиялық ем қабыладған пациенттерде емделуге дейін жалпы өмір сүруді де, рецедивсіз өмір сүруді болжайтын жоғары нейтрофилдің лимфоциттерге қатынасы индексі, тромбоциттерге қатынасы индексі және жүйелік иммунды-қабыну индексі қолайсыз болжамды фактор болып табылды. Көп факторлы талдау нәтижесінде тромбоциттердің лимфоциттерге жоғары қатынасы жалпы өмір сүру үшін де, рецедивсіз өмір сүру үшін де қолайсыз болжам факторы екендігі анықталды.

Негізгі сөздер: асқазанның қатерлі ісігі, индекс соотношения нейтрофилдер мен лимфоциттердің қатынасы индексі, тромбоциттер мен лимфоциттердің қатынасы индексі, болжам

\section{ПРОГНОСТИЧЕСКАЯ ЦЕННОСТЬ ИНДЕКСА СООТНОШЕНИЯ НЕЙТРОФИЛОВ И ЛИМФОЦИТОВ, ИНДЕКСА СООТНОШЕНИЯ ТРОМБОЦИТОВ И ЛИМФОЦИТОВ И СИСТЕМНОГО ИММУНО-ВОСПАЛИТЕЛЬНОГО ИНДЕК- СА ПРИ РАКЕ РЕЗЕЦИРОВАННОГО ЖЕЛУДКА}

Х. Шахинли, С. Туркер

Отделение медицинской онкологии, Университетская больница Анкары Дышкапы Йылдырым Беязит, Анкара, Турция

\section{PEЗЮME}

Цель: Прогностическая ценность индекса соотношения нейтрофилов и лимфоцитов, индекса соотношения тромбоцитов и лимфоцитов и системного иммуно-воспалительного индекса изучена при многих типах рака. Целью нашего исследования является показать прогностическую ценность индекса соотношения нейтрофилов и лимфоцитов, индекса соотношения тромбоцитов и лимфоцитов и системного иммуно-воспалительного индекса у пациентов с раком резецированного желудка. А также определить, какой параметр является лучшим прогностическим фрактором для выживания.

Материалы и методы: В исследование было включено 95 пациентов с раком резецированного желудка в период с 2014 по 2018 годы. Для определения пороговых значений индекса соотношения нейтрофилов и лимфоцитов, индекса соотношения тромбоцитов и лимфоцитов и системного иммуно-воспалительного индекса был использован анализ кривой операционных характеристик приёмника. Системный иммуно-воспалительный индекс рассчитывали как нейтрофилхтромбоцит/лимфоцит. Были использованылогарифмический ранговый критерий и анализ регрессии Кокса

Результаты: Средний возраст пациентов составил 62 (22-84) года. Медиана общей выживаемости составила 33 месяца. У 49 (51.6\%) пациентов была 3 стадия и у 46 (48.4 \%) пациентов была 1-2 стадия. Высокие значения индекса соотношения нейтрофилов и лимфоцитов, индекса соотношения тромбоцитов и лимфоцитов и системного иммуно-воспалительного индекса, глубина опухоли, стадия метастатического лимфатического узла и стадия системы классификации злокачественных опухолей были неблагоприятными прогностическими фракторами для общей выживаемости и безрецедивной выживаемости. После проведения многовариантного анализа регрессии Кокса, было установлено, что только соотношение тромбоцитов и лимфоцитов является независимым прогностическим фрактором (р = 0.037 для общей выживаемости, $\mathrm{p}=0.024$ для безрецедивной выживаемости).

Заключение: Выявлено, что высокий индекс соотношения нейтрофилов и лимфоцитов, индекс соотношения тромбоцитов и лимфоцитов и системный иммуно-воспалительный индекс являются неблагоприятными прогностическими фракторами в прогнозировании как общей выживаемости, так и безрецедивной выживаемости до лечения у пациентов, перенесших радикальное оперативное вмешательство при раке желудка. В результате многовариантного анализа было выявлено, что только высокое соотношение тромбоцитов к лимфоцитам является независимым неблагоприятным прогностическим фактором как для общей выживаемости, так и для безрецедивной выживаемости

Ключевые слова: рак желудка, индекс соотношения нейтрофилов и лимфоцитов, индекс соотношения тромбоцитов и лимфоцитов, прогноз

\section{Introduction}

Gastric cancer (GC) is the third cause of cancer-related death and the fifth most common worldwide cancer diagnosis [1]. In 2018, 1.03 million new cases were diagnosed and 780,000 deaths occurred due to gastric cancer [2]. Despite advances in early diagnosis and treatment, one-third of gastric cancer patients who underwent curative surgery had recurrence [3-5]. The established prognostic factors were tumor depth (T), stage of metastatic lymph node $(\mathrm{N})$, tumor-node-metastasis (TNM) stage and histological type of tumor [4,6]. However, the prognosis is different even in patients with the same stage [7]. Therefore, studies are conducted to investigate different factors affecting prognosis.

Systemic inflammatory response is a complex bio-system involving humoral and cellular components. These systemic inflammatory biomarkers have been reported to be associated with poor outcomes in patients with gastric cancer. Of these biomarkers, high neutrophil-lymphocyte ratio (NLR), plateletlymphocyte ratio (PLR) and systemic immune-inflammatory index (SII) have been reported to be associated with poor prognosis $[3,5,8]$.However, the clinical relevance of a blood score that combines NLR, PLR and SII has not been in patients with gastric cancer.

The aim of this study is to determine which one of these three systemic inflammatory markers is better for patients with gastric cancer.

\section{Material and methods}

The study included 95 patients with gastric cancer diagnosed and operated in the Medical Oncology Clinic of Ankara Dışkapı YıldırımBeyazıt Training and Research Hospital between 2014-2018. Patients with metastasis, patients with active infection before treatment and patients with missing file records were excluded from the study. The tumors were staged according to the TNM staging system of the American Joint Committee on Cancer (AJCC 7th ed., 2010). Clinicopathological details, pretreatment laboratory data, survival data were collected by review of patients record, retrospectively. All patients underwent either a subtotal or total gastrectomy with standard D2 lymphadenectomy 
The NLR was defined as the absolute neutrophil count divided by the absolute lymphocyte count. Similarly, the PLR was defined as the absolute platelet count divided by the absolute lymphocyte count. Systemic immune-inflammatory index was calculated as plateletxneutrophil / lymphocyte.

The study was conducted according to the principles of the Declaration of Helsinki. The study was approved by the Ethics Committee of the Ankara Dışkapı Yılsırım Beyazıt Training and Research Hospital.

\section{Statistical analysis}

Statistical analyses were performed using SPSS 20.0 program. The optimal cutoff of NLR, PLR and SII were estimated by receiver operating characteristics (ROC) curve. The area under the curve (AUC), sensitivity, and specificity were calculated. The relationship between categorical variables was evaluated by chi-square test. The relationship between PLR, NLR, SII and disease-free survival (DFS), overall survival (OS) was evaluated by Kaplan-Meier method and log rank test. Multivariant analysis was conducted using the Cox regression analysis. $\mathrm{P}<0.05$ was considered statistically significant.

\section{Results}

Clinicopathological features of the patients are summarized in Table 1.69 (72.6\%) patients were male. The median age was 62 years (range 22 to 84 years) at the time of diagnosis. During follow-up, $52(54.7 \%)$ patients developed recurrence and 48 $(50.5 \%)$ patients died. $68(71.6 \%)$ patients received adjuvant therapy. 5- fluorouracil (5 FU) based chemotherapy was given as adjuvant chemotherapy in all patients.

For NLR, the best cut-off value estimated by ROC analysis was 2.66 . The area under the curve(AUC) was 0.644 , sensitivity $60.4 \%$, specificity $68.1 \%$. The number of patients with NLR less than 2.66 was 51 and the number of patients with high NLR was 44. Overall survival of patients with NLR above 2.66 was shorter than those with low NLR $(\mathrm{p}=0.003)$. Overall survival was 21 months in the NLR high group, whereas DFS was not reached in the NLR low group (Figure 1a). Disease-free survival was significantly shorter in the NLR-high group than in the NLR-low group $(\mathrm{p}=0.003)$. While DFS was 13 months in the NLR high group, disease-free survival was not reached in the NLR low group (Figure 1b).

\section{Table 1 Clinicopathologicfeatures of operatedgastriccancerpatients}

\begin{tabular}{|c|c|}
\hline Age & $62(22-84)$ \\
\hline Gender (Female/Male n) & $26 / 69$ \\
\hline \multicolumn{2}{|l|}{ TNM Stage (n) } \\
\hline Stage $1 / 2$ & 45 \\
\hline Stage 3 & 49 \\
\hline \multicolumn{2}{|l|}{ Lymph node stage (n) } \\
\hline N0/1 & 47 \\
\hline $\mathrm{N} 2 / 3$ & 47 \\
\hline \multicolumn{2}{|l|}{ Tumor depth (n) } \\
\hline $\mathrm{T} 1 / 2$ & 34 \\
\hline $\mathrm{T} 3 / 4$ & 60 \\
\hline \multicolumn{2}{|l|}{ Adjuvant treatment (n) } \\
\hline Yes & 68 \\
\hline No & 27 \\
\hline \multicolumn{2}{|l|}{ Grade (n) } \\
\hline $1 / 2$ & 35 \\
\hline 3 & 39 \\
\hline
\end{tabular}

TNM: Tumor-node-metastasis

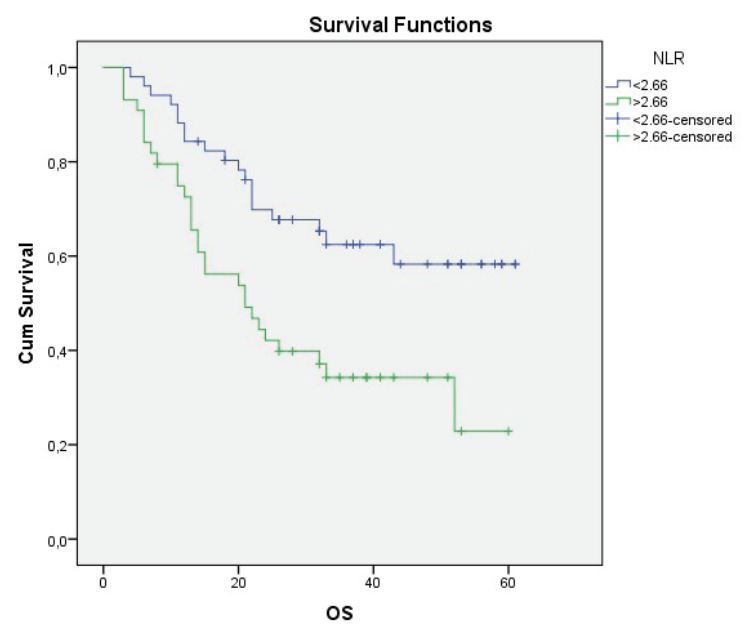

Figure 1a - Kaplan-Meier Curve for Overall survival of low and high neutrophil-lymphocyte ratio

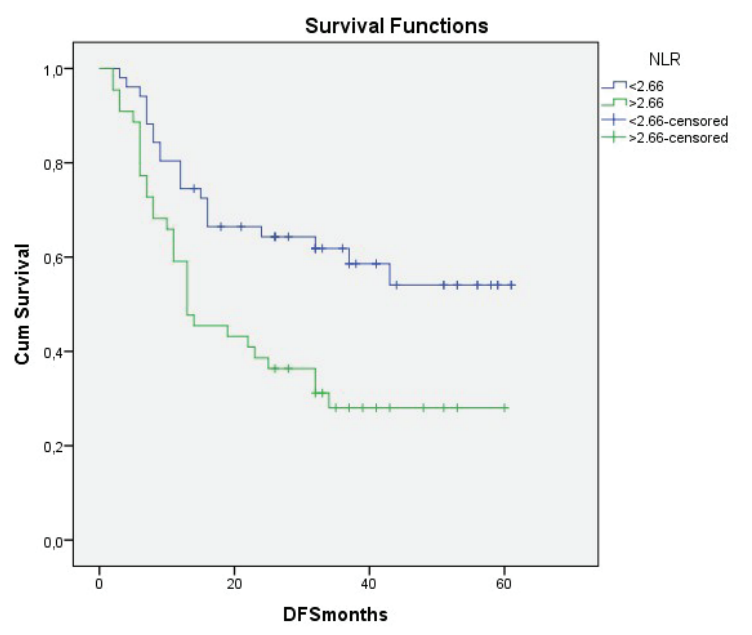

Figure 1b - Kaplan -Meier curvefordisease-free survival of low and high neutrophil-lymphocyte group 
For PLR, the best predicted value was found to be 143 by ROC analysis. The sensitivity was $64.4 \%$, the specificity was $66 \%$, and AUC was 0.663 . While the number of patients with PLR below 143 was 47, the number of patients with PLR above 143 was 48. In the PLR-high group, OS was significantly shorter than the PLR-low group $(\mathrm{p}=0.001)$. In the PLR-high group, OS was 22 months. In the PLR-low group, OS could not be reached (Figure 2a). DFS was shorter in the PLR-high group than in the PLR-low group $(p=0.001)$. The disease-free survival of patients in the PLR-high group was 13 months, while the disease-free survival of patients in the PLR-low group was not reached (Figure 2b).

The best predicted value for SII was 644. There were 47 patients with SII levels above 644 and 48 patients below 644 .

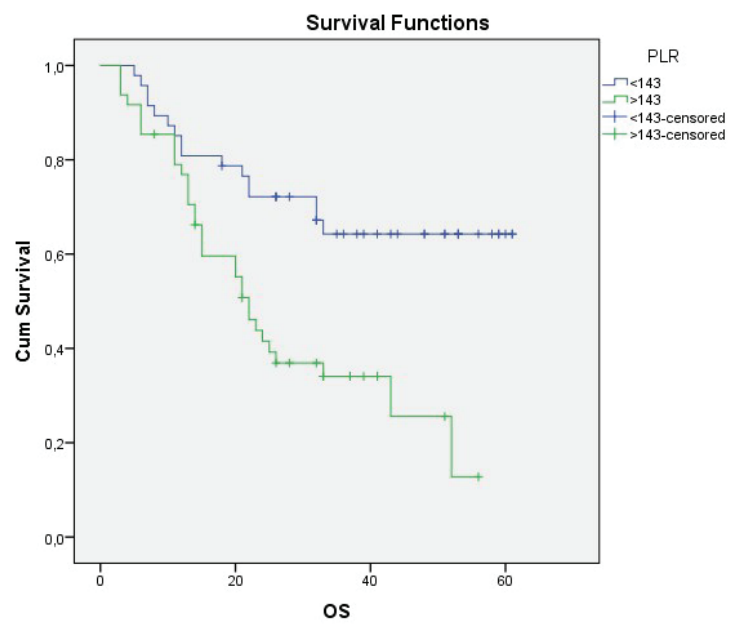

Figure 2a - Kaplan-Meier curve for overall survival of low and high platelet / lymphocyte group

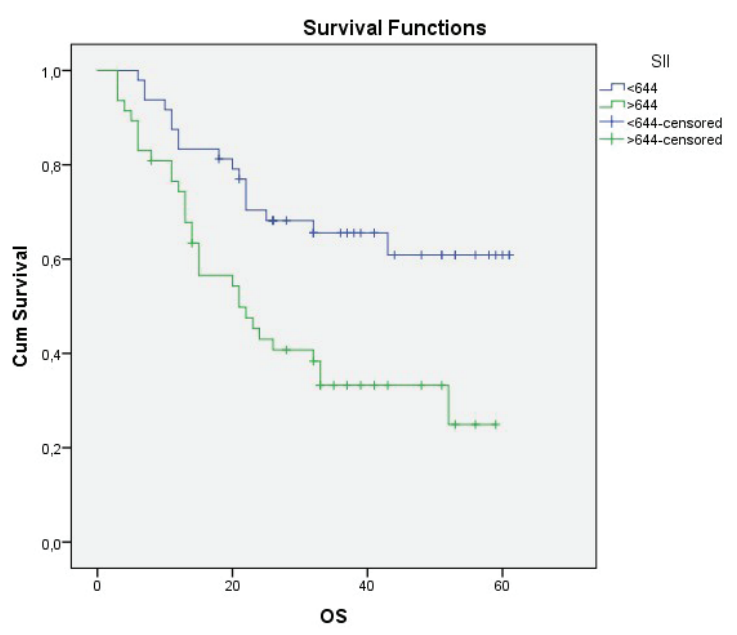

Figure 3a - Kaplan-meier curve for overall survival of low and high systemic immune-inflammatory index group

\section{Prognostic factors}

The median follow-up period was 26 months (range 3-61), and the median OS was 33 months. Prognostic factors for overall survival are summarized in Table 2. In univariant analysis, TNM stage, N stage, T stage, adjuvant therapy, NLR, PLR and SII values were statistically significant prognostic factors on overall survival, whereas age and gender were not significant prognostic
In the ROC analysis, AUC was 0.663 , sensitivity $64.4 \%$ and specificity $66 \%$. Overall survival in the high SII group was significantly shorter than in the low SII group $(\mathrm{p}=0.002)$. While OS was 21 months in the high SII group, the OSwas not reached in the low SII group (Figure 3a). DFS in the high SII group was significantly shorter than the low SII group $(p=0.001)$. While DFS was 13 months in the high SII group, the DFS duration was not reached in the low SII group (Figure 3b).

When we looked at the relationship between NLR, PLR and SII values and clinicopathologic variables, only SII was associated with high TNM stage $(p=0.046)$. Age, gender, $T$ stage, $\mathrm{N}$ stage, grade, need for adjuvant therapy were not associated with NLR, SII and PLR.

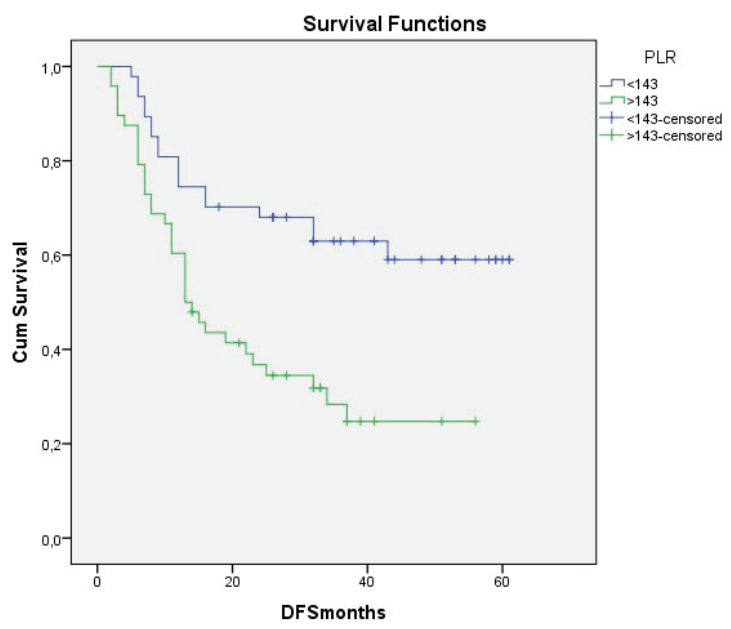

Figure 2b - Kaplan-meier curve for disease-free survival of low and high platelet / lymphocyte group

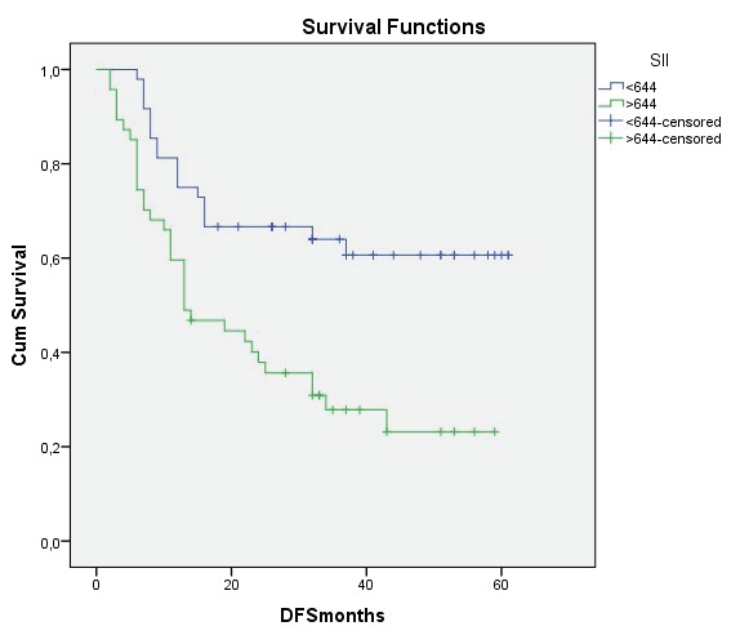

Figure 3b - Kaplan-meier curve for disease-free survival of low and high systemic immune-inflammatory index group

factors. Overall survival was shorter in patients with high NLR, high PLR, high SII, TNM stage 3 disease, N stage 3/4 and T stage 3/4. Multivariate analysis showed that PLR was independent prognostic factor (Table 2). Median OS and DFS were poor in the high PLR group ( $p=0.037$ for GSK, $p=0.024$ for HSK). 


\begin{tabular}{|l|l|l|l|l|}
\hline $\begin{array}{l}\text { Univariate } \\
\text { analysis }\end{array}$ & & & \multicolumn{2}{l|}{ Multivariate analysis } \\
\hline Variables & $\begin{array}{l}\text { P value } \\
\text { (long rank) }\end{array}$ & $\begin{array}{l}\text { Hazard } \\
\text { ratio }\end{array}$ & $95 \%$ Cl & p value \\
\hline Age & 0.289 & & & \\
\hline$<65 />65$ & & & & \\
\hline Sex & 0.193 & & & \\
\hline Female/male & & & & \\
\hline TNM stage & 0.000 & 0.578 & $0.130-2.568$ & 0.472 \\
\hline Stage 1-2/3 & & & & \\
\hline $\begin{array}{l}\text { Lymph node } \\
\text { metastasis }\end{array}$ & 0.000 & 0.748 & $0.204-2.748$ & 0.662 \\
\hline N1-2/3-4 & & & & \\
\hline Depth of tumor & 0.000 & 0.735 & $0.269-2.008$ & 0.548 \\
\hline T1-2/3 & & & & \\
\hline Adjuvant therapy & 0.002 & 1.911 & $0.749-4.872$ & 0.175 \\
\hline Yes/no & & & & \\
\hline NLR & 0.003 & 0.824 & $0.369-1.839$ & 0.636 \\
\hline$<2 />2$ & & & & \\
\hline PLR & 0.001 & 2.202 & $1.049-4.622$ & 0.037 \\
\hline$<143 />143$ & & & & \\
\hline SII & 0.002 & 0.908 & $0.388-2.125$ & 0.823 \\
\hline$<644 />644$ & & & & \\
\hline
\end{tabular}

TNM: Tumor-node-metastasis, NLR: neutrophil / lymphocyte ratio, PLR: platelet / lymphocyte ratio, SII: systemic immune-inflammatory index

\section{Discussion}

The aim of this study was to investigate the prognostic value of pre-treatment NLR, PLR and SII levels in patients with resected gastric cancer. In this study, high NLR, PLR and SII values were found to be associated with short disease-free survival and overall survival. Cox regression analysis showed that high PLR was an independent poor prognostic factor associated with OS and DSF.

Clinical and epidemiological studies have shown a strong association between acute / chronic infection and cancer [9-11]. Helicobacter pylori infection is characterized by inflammatory infiltration of T cells and neutrophils [12].Chronic inflammation associated with infections and autoimmune diseases has been proven to play an important role in the development and/ or progression of several cancer [13,14]. Defense cells of the immune system (neutrophils, macrophages, lymphocytes, natural killer cells, dendritic cells) and cytokines released from these cells may cause tumor growth and metastasis [15]. Inflammation results in an increase in neutrophils and platelets and a decrease in lymphocytes $[16,17]$.
Lymphocytes play an important role in the immune response and are the most important cells in eliminating cancer cells and suppressing cancer development [18].Studies in many cancer types have shown that lymphocytopenia is associated with poor prognosis [19].

The relationship between trombocytosis and cancer has long been known. Platelets have an important role in tumor growth, formation and metastasis [20,21]. Platelets also inhibit the antitumor effects of NK cells, causing tumor cells to grow and spread [4]. High platelet count has been shown to cause short survival in many cancer types [16,22-26].

Neutrophil cells contribute to the formation, proliferation and spread of cancer cells. The role of neutrophil in the development of metastasis is due to the release of reactive oxygen products, nitric oxide, vascular endothelial growth factor. Increased neutrophils also supressthe activity of lymphocyte, natural killer and activated T cells [27,28].High neutrophil and platelet count and low lymphocyte count lead to high systemic immune-inflammatory index value. High SII is an indicator of strong inflammation and weak immune response in cancer patients. SII has been associated with poor survival in many solid tumors [29].Studies have shown that increased NLR, PLR and SII levels are associated with poor outcomes in patients with gastric cancer [8].In our study, high PLR, NLR and SII values were found to be associated with poor prognosis. However, the most important predictor of prognosis was PLR.

These parameters are required as routine blood tests from all patients before treatment. One of the aims of our study was to emphasize the importance of the inflammatory system in operated gastric cancer patients. Our other aim was to determine the best parameter that could help clinicians predict prognosis in patients with operated gastric cancer.

Because of our study was a single center data, it included a small number of patients. In addition, our study was performed retrospectively and all factors that could affect prognosis could not be evaluated. Therefore, prospective studies are needed.

\section{Conclusion}

There is no study on which one of these reliable and inexpensive markers is better. In our study, high PLR, NLR and SII values before treatment were found to be poor prognostic markers. However, only PLR was found to be an independent prognostic factor. Our study shows that PLR is a better prognostic factor than the others in patients with operated gastric cancer.

Disclosures: There is no conflict of interest for all authors.

Ethics approval: The retrospective observational study was approved by the ethics committee of the Ankara Dişkapı Yıldırım Beyazıt Training and Researc Hospital.

\section{References}

1. Ferlay J, Soerjomataram I, Dikshit R, Eser S, Mathers C, Rebelo M, et al. Cancer incidence and mortality worldwide: sources, methods and major patterns in GLOBOCAN 2012. Int J Cancer. 2015;136(5):E359-86.https://doi.org/10.1002/ijc.29210

2. Torre LA, Bray F, Siegel RL, Ferlay J, Lortet-Tieulent J, Jemal A. Global cancer statistics, 2012. CA Cancer J Clin. 2015; 65(2):87-108. https://doi.org/10.3322/caac. 21262

3. Powell A, Parkinson D, Patel N, Chan D, Christian A, Lewis WG. Prognostic Significance of Serum Inflammatory Markers in Gastric Cancer. J Gastrointest Surg. 2018; 22(4):595-605. https://doi.org/10.1007/s11605-017-3597-5

4. Zhang Y, Lu JJ, Du YP, Feng CX, Wang LQ, Chen MB. Prognostic value of neutrophil-to-lymphocyte ratio and platelet-to-lymphocyte ratio in gastric cancer. Medicine (Baltimore). 2018;97(12):e0144.https://doi.org/10.1097/MD.0000000000010144

5. Mellor KL, Powell A, Lewis WG. Systematic Review and Meta-Analysis of the Prognostic Significance of Neutrophil-Lymphocyte 
Ratio (NLR) After R0 Gastrectomy for Cancer. J Gastrointest Cancer. 2018; 49(3):237-44. https://doi.org/10.1007/s12029-018-0127-y

6. Zhu YL, Yang L, Sui ZQ, Liu L, Du JF. Clinicopathological features and prognosis of Borrmann type IV gastric cancer. J BUON. 2016; 21(6):1471-5.

7. Shah MA, Ajani JA. Gastric cancer--an enigmatic and heterogeneous disease. JAMA. 2010; 303(17):1753-4. https://doi.org/10.1001/ jama.2010.553

8. Zhang X, Zhang W, Feng LJ. Prognostic significance of neutrophil lymphocyte ratio in patients with gastric cancer: a meta-analysis. PLoS One. 2014;9(11):e111906.https://doi.org/10.1371/journal.pone.0111906

9. Coussens LM, Werb Z. Inflammation and cancer. Nature. 2002; 420(6917):860-7.https://doi.org/10.1038/nature01322

10. Pardoll DM. Spinning molecular immunology into successful immunotherapy. Nat Rev Immunol. 2002;2(4):227-38.https://doi. org/10.1038/nri774

11. Homey B, Muller A, Zlotnik A. Chemokines: agents for the immunotherapy of cancer? Nat Rev Immunol. 2002; 2(3):175-84. https:// doi.org/10.1038/nri748

12. Amedei A, Munari F, Bella CD, Niccolai E, Benagiano M, Bencini L, et al. Helicobacter pylori secreted peptidyl prolyl cis, transisomerase drives Th17 inflammation in gastric adenocarcinoma. Intern Emerg Med. 2014;9(3):303-9.https://doi.org/10.1007/s11739012-0867-9

13. Kubota T, Hiki N, Nunobe S, Kumagai K, Aikou S, Watanabe R, et al. Significance of the inflammation-based Glasgow prognostic score for short- and long-term outcomes after curative resection of gastric cancer. J Gastrointest Surg. 2012;16(11):2037-44.https://doi. org/10.1007/s11605-012-2036-X

14. Hanahan D, Weinberg RA. Hallmarks of cancer: the next generation. Cell. 2011;144(5):646-74.https://doi.org/10.1016/j.cell.2011.02.013

15. Todoric J, Antonucci L, Karin M. Targeting Inflammation in Cancer Prevention and Therapy. Cancer Prev Res (Phila). 2016; 9(12):895905. https://doi.org/10.1158/1940-6207.CAPR-16-0209

16. Shoda K, Komatsu S, Ichikawa D, Kosuga T, Okamoto K, Arita T, et al. Thrombocytosis Associated with Poor Prognosis in Patients with Gastric Cancer. Gan To Kagaku Ryoho. 2015; 42(12):1980-2.

17. Chen Y, Zhang L, Liu WX, Liu XY. Prognostic significance of preoperative anemia, leukocytosis and thrombocytosis in chinese women with epithelial ovarian cancer. Asian Pac J Cancer Prev. 2015;16(3):933-9.https://doi.org/10.7314/APJCP.2015.16.3.933

18. Dunn GP, Old LJ, Schreiber RD. The immunobiology of cancer immunosurveillance and immunoediting. Immunity. 2004; 21(2):13748. https://doi.org/10.1016/j.immuni.2004.07.017

19. Dupre A, Malik HZ. Inflammation and cancer: What a surgical oncologist should know. Eur J Surg Oncol. 2018; 44(5):566-70. https:// doi.org/10.1016/j.ejso.2018.02.209https://doi.org/10.1016/j.ejso.2018.02.209

20. Digklia A, Voutsadakis IA. Thrombocytosis as a prognostic marker in stage III and IV serous ovarian cancer. ObstetGynecol Sci. 2014;57(6):457-63.https://doi.org/10.5468/ogs.2014.57.6.457

21. Voutsadakis IA. Thrombocytosis as a prognostic marker in gastrointestinal cancers. World J Gastrointest Oncol. 2014; 6(2):34-40. https://doi.org/10.4251/wjgo.v6.i2.34

22. Cao W, Yao X, Cen D, Zhi Y, Zhu N, Xu L. Prognostic role of pretreatment thrombocytosis on survival in patients with cervical cancer: a systematic review and meta-analysis. World J Surg Oncol. 2019; 17(1):132. https://doi.org/10.1186/s12957-019-1676-7

23. Hirahara T, Arigami T, Yanagita S, Matsushita D, Uchikado Y, Kita Y, et al. Combined neutrophil-lymphocyte ratio and plateletlymphocyte ratio predicts chemotherapy response and prognosis in patients with advanced gastric cancer. BMC Cancer. 2019;19(1):672. https://doi.org/10.1186/s12885-019-5903-y

24. Riedl J, Pabinger I, Ay C. Platelets in cancer and thrombosis. Hamostaseologie. 2014; 34(1):54-62.https://doi.org/10.5482/HAMO-1310-0054

25. Sasaki K, Kawai K, Tsuno NH, Sunami E, Kitayama J. Impact of preoperative thrombocytosis on the survival of patients with primary colorectal cancer. World J Surg. 2012; 36(1):192-200.https://doi.org/10.1007/s00268-011-1329-7

26. Guo T, Krzystanek M, Szallasi Z, Szallasi A. Thrombocytosis portends adverse prognostic significance in patients with stage II colorectal carcinoma. F1000Res. 2014; 3:180.https://doi.org/10.12688/f1000research.4856.1

27. Graziosi L, Marino E, De Angelis V, Rebonato A, Cavazzoni E, Donini A. Prognostic value of preoperative neutrophils to lymphocytes ratio in patients resected for gastric cancer. Am J Surg. 2015; 209(2):333-7. https://doi.org/10.1016/j.amjsurg.2014.06.014

28. Sun X, Liu X, Liu J, Chen S, Xu D, Li W, et al. Preoperative neutrophil-to-lymphocyte ratio plus platelet-to-lymphocyte ratio in predicting survival for patients with stage I-II gastric cancer. Chin J Cancer. 2016;35(1):57.https://doi.org/10.1186/s40880-016-0122-2

29. Zhong JH, Huang DH, Chen ZY. Prognostic role of systemic immune-inflammation index in solid tumors: a systematic review and metaanalysis. Oncotarget. 2017;8(43):75381-8.https://doi.org/10.18632/oncotarget.18856

How to cite this article: Hayriye Şahinli, SemaTurker. Prognostic value of neutrophil-lymphocyte ratio, plateletlymphocyte ratio and systemic immune-inflammatory index in resected gastric cancer. J Clin Med Kaz. 2019; 4(54):34-39 